\title{
SPEAKING SKILLS DEVELOPMENT IN ESL E-LEARNING EDUCATIONAL ENVIRONMENT
}

\author{
DESENVOLVIMENTO DE HABILIDADES DE FALA NO AMBIENTE \\ EDUCACIONAL ISL E-LEARNING
}

\author{
DESARROLLO DE HABILIDADES HABLANTES EN ESL ENTORNO EDUCATIVO E- \\ LEARNING
}

\author{
Safin Ildar KHAMZOVICH ${ }^{1}$ \\ Khasanova Oxana VLADIMOROVNA ${ }^{2}$ \\ Karimova Anna ANATOLYEVNA ${ }^{3}$ \\ Semushina Elena YURIEVNA ${ }^{4}$ \\ Shustova Svetlana VIKTOROVNA ${ }^{5}$
}

ABSTRACT: The article focuses on the peculiarities of teaching speaking in e-learning educational environment, which today is a must for organizing educational process of high quality. The material to analyze is based on the on-line part of the course "Foreign language practice (English)", worked for the students of Bachelor's Program "Pedagogical Education (double major) and Second Foreign language" (5 years, full-time) of Kazan Federal University. The status of foreign language teachers has always been high, since they play an important role in fostering cross-cultural communication, in promoting tolerance and bridging nations and countries. It is up to teachers to make students understand the essence of successful communication that lies in respecting the diversity of cultures, peoples, nations, and languages. Being culturally competent is of great importance to this goal (MINGAZOVA; MELLO; GAFIYATOVA, 2017). The course "Foreign language practice (English)" is located on the platform edu.kpfu.ru. Special attention is paid to the implementation of a communicative approach when teaching how to speak, considering the individual educational trajectory of the student or the study group. In addition, the research gives the gist of the theoretical analysis and the results of the experimental testing of the approaches of teaching how to speak, the effectiveness of the methods used when forming speaking skills of the students. Thus, we could state that when teaching how to speak in e-

\footnotetext{
${ }^{1}$ Kazan Federal University (KPFU), Kazan - Russia. Assistant at the Department of Theory and Practice of Teaching Foreign Languages, Institute of Philology and Intercultural Communication. ORCID: https://orcid.org/0000-0001-6037-1901. E-mail: svr_ifi@mail.ru]

${ }^{2}$ Kazan Federal University (KPFU), Kazan - Russia. Associate Professor of the Department of Theory and Practice of Teaching Foreign Languages, Institute of Philology and Intercultural Communication. Candidate of Pedagogy. ORCID: https://orcid.org/0000-0002-4979-3238. E-mail: khasanova_oxana@rambler.ru

${ }^{3}$ Kazan Federal University (KPFU), Kazan - Russia. Associate Professor of the Department of Theory and Practice of Teaching Foreign Languages, Institute of Philology and Intercultural Communication. Candidate of Pedagogy. ORCID: https://orcid.org/0000-0002-0908-8243. E-mail: an.carimova2012@yandex.ru

${ }^{4}$ Kazan Federal University (KPFU), Kazan - Russia. Associate Professor of the Department of Foreign Languages in Professional Communication. PhD in Philology. ORCID: https://orcid.org/0000-0002-7453-5695. E-mail: epospelova12@yandex.ru

${ }^{5}$ Perm State National Research University (PSU), Perm - Russia. Professor of the Department of Linguistics and Translation, Faculty of Modern Foreign Languages and Literatures and Professor of the Department of Theoretical and Applied Linguistics, Philological Faculty. Doctor of Philology. ORCID: https://orcid.org/00000002-8318-7864. E-mail: lanaschust@mail.ru
} 
learning educational environment, it is necessary to conduct preparatory stages in the form of studying and training new vocabulary online, which leads to the possibility to give more time to group forms of work during face-to-face classes. The groundwork and analysis of the selected factual material indicate that, teaching how to speak can be effectively carried out online, if certain requirements are met, such as the use of a communicative approach, the proper organization of individual and group work, high self-discipline and motivation of the student and the teacher. The use of e-learning educational environment can improve the quality of formation on speaking skills in higher educational institution.

KEYWORDS: e-learning educational environment. Educational process. Foreign language practice. Speaking skills. Communicative method.

RESUMO: O artigo enfoca as peculiaridades do ensino do falar no ambiente educacional elearning, que hoje é uma necessidade para organizar o processo educacional de alta qualidade. O material a ser analisado é baseado na parte on-line do curso "Prática de linguas estrangeiras (inglês)", elaborado para os estudantes do Programa de Bacharelado "Educação Pedagógica (dupla especialização) e Segunda Lingua Estrangeira" (5 anos, periodo integral) da Universidade Federal de Kazan. O status dos professores de línguas estrangeiras sempre foi elevado, pois eles desempenham um papel importante na promoção da comunicação transcultural, na promoção da tolerância e na aproximação entre nações e países. Cabe aos professores fazer com que os alunos compreendam a essência da comunicação bem-sucedida que reside no respeito à diversidade de culturas, povos, nações e línguas. Neste aspecto, ser culturalmente competente é de grande importância (MINGAZOVA; MELLO; GAFIYATOVA, 2017). O curso "Prática de línguas estrangeiras (inglês)" está localizado na plataforma edu.kpfu.ru. É dada atenção especial à implementação de uma abordagem comunicativa ao ensinar a falar, considerando a trajetória educacional individual do aluno ou do grupo de estudo. Além disso, a pesquisa dá o essencial da análise teórica e os resultados dos testes experimentais das abordagens de ensino oral, a eficácia dos métodos usados na formação das habilidades de fala dos estudantes. Assim, poderíamos afirmar que ao ensinar a fala no ambiente educacional de elearning, é necessário conduzir etapas preparatórias na forma de estudo e treinamento de novo vocabulário on-line, o que leva à possibilidade de dar mais tempo às formas de trabalho em grupo durante as aulas presenciais. O trabalho de base e a análise do material factual selecionado indicam que, o ensino da fala pode ser efetivamente realizado on-line, se determinados requisitos forem atendidos, tais como o uso de uma abordagem comunicativa, a organização adequada do trabalho individual e em grupo, alta autodisciplina e motivação do aluno e do professor. $O$ uso do ambiente educacional e-learning pode melhorar a qualidade do treinamento da fala na instituição de ensino superior.

PALAVRAS-CHAVE: Ambiente educacional e-learning. Processo educacional. Prática de linguas estrangeiras. Habilidades de fala. Método comunicativo.

RESUMEN: El artículo se centra en las peculiaridades de la enseñanza del habla en el entorno educativo e-learning, que hoy en dia es imprescindible para organizar procesos educativos de alta calidad. El material a analizar está basado en la parte on-line del curso "Práctica de lengua extranjera (inglés)", elaborado para los alumnos del Programa de Licenciatura "Educación Pedagógica (doble especialización) y Segunda Lengua Extranjera" (5 años, tiempo completo) de la Universidad Federal de Kazán. El estatus de los profesores

RPGE- Revista on line de Política e Gestão Educacional, Araraquara, v. 25, n. esp. 1, p. 577-588, mar. 2021. e-ISSN:1519-9029 
de lenguas extranjeras siempre ha sido alto, ya que desempeñan un papel importante en el fomento de la comunicación intercultural, en la promoción de la tolerancia y en unir naciones y países. Depende de los maestros hacer que los estudiantes comprendan la esencia de una comunicación exitosa que radica en respetar la diversidad de culturas, pueblos, naciones e idiomas. En este sentido, ser culturalmente competente es de gran importancia (MINGAZOVA; MELLO; GAFIYATOVA, 2017). El curso "Práctica de lenguas extranjeras (inglés)" se encuentra en la plataforma edu.kpfu.ru. Se presta especial atención a la implementación de un enfoque comunicativo en la enseñanza del habla, considerando la trayectoria educativa individual del alumno o del grupo de estudio. Además, la investigación da la esencia del análisis teórico y los resultados de las pruebas experimentales de los enfoques de enseñanza oral, la efectividad de los métodos utilizados al formar las habilidades de expresión oral de los estudiantes. Así, podríamos afirmar que a la hora de enseñar a hablar en el entorno educativo e-learning, es necesario realizar etapas preparatorias en forma de estudio y formación de nuevo vocabulario en línea, lo que conlleva la posibilidad de dar más tiempo a formas de trabajo grupal durante el presencial. -Clases presenciales. El trabajo de base y el análisis del material fáctico seleccionado indican que, la enseñanza del habla puede llevarse a cabo de manera efectiva en linea, si se cumplen ciertos requisitos, como el uso de un enfoque comunicativo, la organización adecuada del trabajo individual y grupal, alta autodisciplina y motivación del alumno y del profesor. El uso del entorno educativo de aprendizaje electrónico puede mejorar la calidad de la formación de habilidades para hablar en una institución de educación superior.

PALABRAS CLAVE: Entorno educativo e-learning. Proceso educativo. Práctica de la lengua extranjera. Habilidades de habla. Método comunicativo.

\section{Introduction}

The integration of distance learning into the educational process is of great importance, as the use of information technologies reveals new opportunities for teachers as well as students. Indeed, successfully completing an online course assumes a number of qualities and capabilities on the part of learners. They must be sufficiently committed to work at understanding material without the immediate physical presence of an instructor and peers. This implies skills, abilities, and commitments typically associated with autonomous learners (LIN; ZHANG; ZHENG, 2017). Kazan Federal University today uses two main types of elearning educational environment:

1) distance study, when students are working on their own on the platform edu.kpfu.ru.

2) distance support, when e-learning technologies are used as a part of a full-time educational process for additional development of individual skills. 
e-learning educational environment performs the following functions: organizational, informational, training, developmental, educational, motivational, assessing, and communicative. It has the following peculiarities:

1) individual approach (the student studies at his own pace, the teacher can select the additional elements to study according to the level of knowledge of a particular student);

2) the training course consists of several blocks (modules), which makes it possible not only to choose a specific module to study, but also to combine them in a certain sequence;

3) strengthening the role of independent work of the student, since most tasks involve independent work with on-line resources;

4) development of such qualities as self-discipline and motivation of the student as well as the teacher; the students should organize their time so that they can complete tasks according to the plan, and the teacher should check the tasks on time;

5) E-technologies lead to improving the effectiveness of educational process due to a significant number of links to on-line resources (programs, platforms and so on) being provided on a regular basis as a part of the curriculum.

Training speaking skills in e-learning educational environment is one of the most difficult aspects of e-learning. The problem is that fluent speaking is determined by a good command of the language itself: the rules of grammar, syntax, and vocabulary. In addition, we should keep in mind that the authentic texts (samples of monologue and dialogical speech) must be created by native speakers for native speakers, because they reflect the features and facts of national culture (ZAKIROVA; YASHINA; SHINGAREVA, 2019). The main goal of acquiring a foreign language is the ability to use it in a real situation, so, the fundamental principles of the communicative method are to maximize the time of speech activity when mastering the language and to focus on developing speaking skills. Both educators' and students' roles continue to change including instructors' management, mediation, and accommodations of students' challenges (BLAKE, 2013; DZUBINSKI, 2014; SALMON, 2004). when organizing modern e-learning educational environment.

The purpose of this study is to analyze the features of teaching speaking using elearning technologies in higher educational institutions. 


\section{Methods and materials}

This study examines the organization of training speaking skills in the framework of elearning part of the course "Foreign language practice (English)" for students of Bachelor's Program "Pedagogical Education (double major) and Second Foreign language" of Kazan Federal University. e-learning educational environment has been used at our university since 2010, and at the moment almost all students of this major are the active users of the platform edu.kpfu.ru. The discipline "Foreign language practice (English)" is aimed at improving the language, speech and socio-cultural competence of students as culturally determined beliefs about teaching and learning do shape instructional and learning practices (SADYKOVA; MESKILL, 2019).

The following theoretical and practical research methods are used in the research: review and analysis of scientific resources, comparison of the main approaches to the organization of educational process, modeling, methods of data collection and accumulation, methods of monitoring and measurement, methods of data processing and methods of implementing research results in teaching practice.

\section{Results and discussion}

The research based on the theoretical analysis of the problems of distance learning, teaching speaking in e-learning educational environment and the process of developing speaking skills the pilot work conducted at Kazan Federal University. It has got three stages: ascertaining experiment (identifying the level of speaking skills in the control (16 first-year students) and experiment groups (16 first-year students), formative experiment (implementing specially designed text-based exercises), and control section (monitoring the level of the speaking skills development).

According to the data of the ascertaining experiment the students have problems when fulfilling the speaking tasks especially within e-learning educational environment. The first point (1) shows the general amount of speech difficulties in experimental (EG) and control (CG) groups. The second (2) and the third points (3) in the Figure 1 indicate the difficulties in monological and dialogical speech accordingly. 
Figure 1 - Speech difficulties (the results of the preparatory stage monitoring)

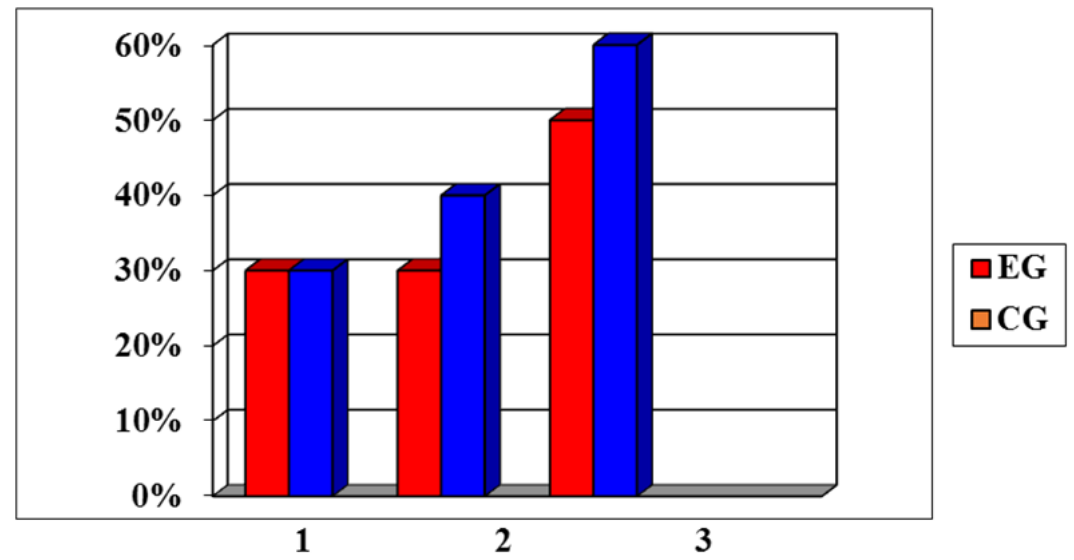

Source: Prepared by the authors

The formative and control experiment stages allowed to reveal the main mistakes when doing specially designed text-based exercises and the stable decline in the amount of the mistakes in the experimental group at both stages: (1) non-conformity speaking assignment; (2) the volume of the statement does not meet the requirements; (3) grammar mistakes; (4) lexical mistakes. As we can see from the table in Figure 2 and Figure 3 the level of drawbacks is getting lower in the experimental group (EG) due to specially organised e-learning educational environment and active teaching technologies. Nevertheless, in the control group we could also see some kind of decline in the amount of mistakes done when speaking but the process of speaking skills development takes more time due to drawbacks, constant repetition and lack of skills of independent work.

Figure 2 - The results of implementing specially designed text-based exercises

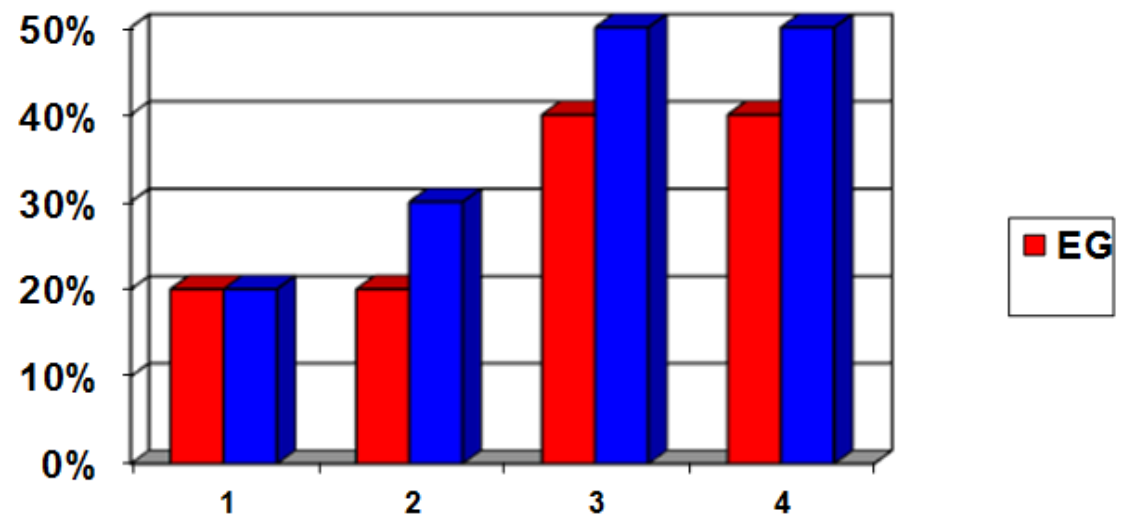

Source: Prepared by the authors 
Figure 3 - The results of implementing specially designed text-based exercises

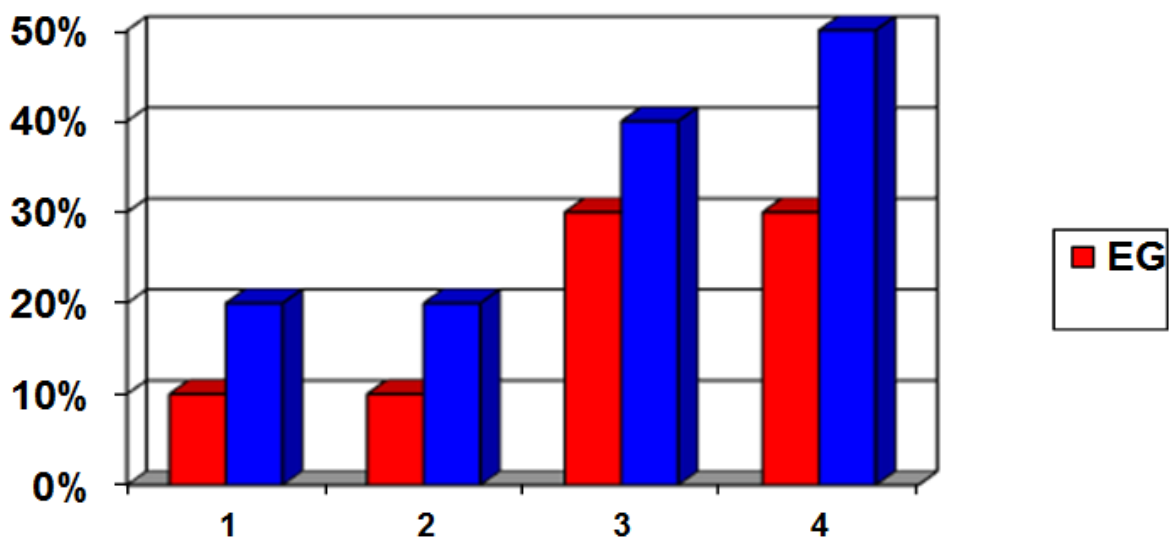

Source: Prepared by the authors

Teaching speaking as the part of e-learning educational environment at Kazan Federal University has the following main features:

1) training speaking skills is based on the communicative approach, that is, the use of the native language is minimized, high motivation of students is formed, group work is aimed at expanding the competence of one participant in communication with other participants; it should be also added that the active use of Internet resources by students in their everyday life leads to the fact that students feel comfortable communicating via video with the teacher and classmates that allows them to use all the principles of the communicative approach successfully;

2) when teaching monologue and dialogue skills in the framework of e-learning environment, the most effective way of teaching speaking is to use the text that has been read before as the basis, since the reading itself and the study of vocabulary from the text can be performed by the student independently, which significantly saves time in the classroom. Large companies such as "Google" and "Yandex" provide applications that contribute to linguistic analysis of different textual unities (GURYANOV et al., 2017). The text the students pre-read characterizes the speech situation (no need to make it up), has a high degree of informativeness (BUDANITSKY; HIRST, 2006), and provides a good basis for imitation. The text material is selected from authentic resources using the Flesch Kincaid scale (recommended readability scores - 40-60 points). The main problem when teaching dialogue skills is that it is not always possible to organize the work on preparing a dialogue effectively, since it is necessary to create a separate virtual room for the preparation of each pair, which is not always possible; 
3) the speaking itself in e-learning educational environment is preceded by vocabulary exercises as preparation stage that can be carried out online, which also allows to save time in the classroom. The ability to communicate in a foreign language depends on how well lexical skills are formed. At the same time, to acquire a lexical unit means to know its form, meaning and usage. Preparation for the speaking presentation takes place at the first two stages of working with the topic-based lexical minimum, the introduction of new vocabulary and doing exercises. Thus, it is better to be carried out using the specially organized e-learning educational environment. The third stage, actualization of the vocabulary, is basically the speaking as the process of presenting the monologue or the dialogue or the other forms of speech. When organizing preparatory work for speaking in the first two stages of working with vocabulary, the following methodological principles are considered: communicative, reliance on the native language (translation tasks), the principle of visibility (links to video material in free access) and accessibility, the principle of gradual formation of lexical skills within each topic (module).

The selection of lexical units is based on the principles of consistency, frequency, compatibility, accessibility and communicative expediency. As part of the e-learning educational environment of the course "Foreign language practice (English)", the following ways of introducing lexical material online are used: using links to video material, wordformation analysis, translation, and working with international terms. Using synonyms/antonyms and guesswork through context have caused certain problems for the students.

To train the lexical material studied in the framework of the analyzed e-learning educational environment, the following exercises are used: to translate the text using new vocabulary, to answer the questions using new vocabulary, to revise the vocabulary with the help of the link to open resource, to do exercises such as, to choose a synonym/antonym, to do multiple choice, to finish a sentence, to insert a word into the text, and to finish a sentence. These exercises can be performed online by the student on his own as well as during the class, depending on the individual trajectory of the student;

4) training speaking in e-learning educational environment allows you to use a differentially organized approach that includes both the language group educational trajectory and the individual educational trajectory of the student. Within each module, two levels of tasks are presented, intermediate and advanced, which are selected by the teacher;

5) the structure of the online course corresponds to the curriculum and work program of the discipline, so that the student can easily find the necessary course elements. Each 
module corresponds to the study of one topic in full-time classes and has a semantic completeness;

6) using webinars instead of traditional form of the lesson becomes a necessary part of teaching speaking held online. Preparation for a webinar requires from a teacher some special comprehension skill, including setting goals and objectives, mindful pre-study of the content, and reasoning the strategies for using the e-learning tools. Besides, additional requirements are imposed on a teacher who is engaged in e-learning educational environment, such as the knowledge of the set of E-technologies at a sufficiently high level, the ability to adapt a traditional off-line course to a distance learning educational Internet platform, motivating students and so on. The software product used for organizing a webinar should have a high level of sound and video effects, a list of supporting devices, and user-friendly interface. Using the educational Internet platform, the teacher has an opportunity to interact with the students, switching on and off the audio of any of the students, demonstrating the screen of the computer or presenting something by himself or to give the students some task to fulfill providing the immediate feedback. The teacher and students can use the chat, attach the taskbased documents, use the white board and the screen share function, and record the webinars (SEMUSHINA; GALEEVA; GALIULLINA, 2014). The type of the webinar and the length of it should depend on the course structure. In other words, the number of webinars should be related to the number of the modules.

\section{Summary}

Within e-learning educational environment speaking is one of the most important aspects of educational process since the real knowledge of a foreign language means the ability to communicate in it. So, the communicative approach in teaching foreign languages is the most effective one. At the same time, the use of information technologies and active use of Internet communication within the specially organized e-learning educational environment can improve the education quality. On-line communicating of the teacher and students has certain features such as teaching forms of speaking should be based on the text already read, since the student can perform this text and study the text vocabulary independently, which significantly saves time. A special role is played by the preparation for speaking in two stages of work (introduction and training) on the lexical basic list that will be used later in speaking. e-learning educational environment allows you to use a differentiated approach, as the selection of material for work can be made by the teacher considering the goals, objectives 
and the educational trajectory of the group and each student. If e-learning educational environment is organized in combination with full-time classes, the structure of the distance course should clearly correspond to the curriculum.

The results achieved due to specially organized e-learning educational environment:

- $\quad$ personal: personal motivation to learn a foreign language and self-reflection;

- $\quad$ subject matter: development of speech and communication skills, the development of verbal skills and the ability to read aloud, while respecting the relevant rules and intonation;

- metaobject matter: the correct use of lexical units in speech, according to the situation of communication; the ability to correct one's own actions, based on their analysis of the mistakes made while speaking; the ability to perceive and use the interactive board; development of the ability to construct speech in accordance with the given tasks.

\section{Conclusions}

Thus, the research and analysis of the selected factual material indicate that, in general, the process of teaching speaking can be effectively carried out online if certain requirements are met, such as the use of a communicative approach, high self-discipline and motivation of the teacher and student, highly developed independent work skills of the student. The main results of this research might be of interest to the specialists in the field of foreign language teaching. The results of the analysis can be used for creating online training courses or distance support for full-time foreign language training.

Thus, the theoretical and practical research has achieved the objective of the research through the step-by-step implementation of the sub-goals and has revealed that in e-learning educational environment the role of the teacher, whose main task is to support and direct the development of the student personality, is changing. More than that the teacher-student relations should be based on the principles of collaborative inquiry-based learning. So, in the present circumstances some changes in the current organizational forms of educational work is inevitable.

ACKNOWLEDGEMENTS: The work is performed according to the Russian Government Program of Competitive Growth of Kazan Federal University. 


\section{REFERENCES}

BLAKE, R. Best practices in online learning: is it for everyone? Rubio and Thoms, p. 10-26, 2013.

BUDANITSKY, A.; HIRST, G. Evaluating wordnet-based measures of lexical semantic relatedness. Computational linguistics, v. 32, n. 1, p. 13-47, 2006.

DZUBINSKI, L. Teaching presence: co-creating a multi-national online learning community in an asynchronous classroom. Online Learning Journal, v. 18, n. 2, 2014).

GURYANOV, I. O. et al. It tools in discourse analysis: state of affairs and problems. AD ALTA-Journal of Interdisciplinary Research, v. 7, n. 2, p. 236-238, 2017.

LIN, C. H.; ZHANG, Y.; ZHENG, B. The roles of learning strategies and motivation in online language learning: A structural equation modeling analysis. Computers \& Education, v. 113, p. 75-85, 2017.

MINGAZOVA, N.; MELLO, H.; GAFIYATOVA, E. Academic and cultural exchange in online teaching $I n$ : INTERNATIONAL CONFERENCE ON EDUCATION AND NEW LEARNING TECHNOLOGIES, 9., 2017, Barcelona. Proceedings [...]. Barcelona, Spain: EDULEARN17, 2017. p. 7864-7867.

SADYKOVA, G.; MESKILL, C. Interculturality in online learning: instructor and student accommodations. Online Learning, v. 23, n. 1, p. 5-21, 2019.

SALMON, G. E-moderating: the key to teaching and learning online. 2. ed. London: Taylor \& Francis, 2004. 284 p.

SEMUSHINA, E.; GALEEVA, M.; GALIULLINA, G. Peculiarities of teaching speaking in distant form as a part of formation of translator's conference of technical specialists. In:

SGEM Conference on Psychology and Psychiatry, Sociology and Healthcare, Education. 2014. p. 641-648.

ZAKIROVA, L. R.; YASHINA, M. Y.; SHINGAREVA, A. S. Peculiarities of teaching listening using authentic ecological materials in the senior secondary school. Humanities \& Social Sciences Reviews, v. 7, n. 6, p. 505-508, 2019. 


\section{How to reference this article}

KHAMZOVICH, S. I.; VLADIMOROVNA, K. O.; ANATOLYEVNA, K. A.; YURIEVNA, S. E.; VIKTOROVNA, S. S. Speaking skills development in ESL E-learning educational environment. Revista on line de Política e Gestão Educacional, Araraquara, v. 25, n. esp.1, p. 577-588, mar. 2021. e-ISSN:1519-9029. DOI: https://doi.org/10.22633/rpge.v25iesp.1.14998

Submitted: 06/11/2020

Required revisions: 18/01/2021

Approved: $23 / 02 / 221$

Published: 01/03/2021 